\title{
Genetic diversity and population structure of Seriphidium Sub-genus of Artemisia from different terrains of Balochistan, Pakistan
}

\author{
ABDUL REHMAN, SHAZIA SAEED ${ }^{\boldsymbol{\nu}}$, ALIA AHMED \\ Department of Botany, University of Balochistan. Quetta 87300, Pakistan. Tel./fax.: +92-81-921-1264. "email: shazia_botany@yahoo.com, \\ aliaahmed_botany@yahoo.com \\ Manuscript received: 3 February 2021. Revision accepted: 19 April 2021.
}

\begin{abstract}
Rehman A, Saeed S, Ahmed A. 2021. Genetic diversity and population structure of Seriphidium Sub-genus of Artemisia from different terrains of Balochistan, Pakistan. Biodiversitas 22: 2658-2664. Seriphidium is one of the largest sub-genus of Artemisia growing in different geographical populations and terrains of Balochistan Pakistan. This genus is economically important and used as folk medicine. The genus is highly variable, besides morphological characterization, molecular authentication is also needed for novel drug discovery. Three significant species of the genus viz., S. quettense, S. oliverianum, and S. maritimum were selected for morphological and molecular characterization and phytochemical investigation. Genetic variability assessment was carried out by polymorphic bands analysis by using molecular markers in 18 accessions collected from two sites, namely, Ziarat and HazarganjiChiltan National Park, Balochistan, Pakistan. A combined molecular marker system by using 17 Randomly Amplified Polymorphic DNA (RAPD) and 9 Inter-Simple Sequence Repeats (ISSR) amplified 231 loci, of which 111 were polymorphic (48\% polymorphism). Phenolic contents and Flavonoids were estimated for phytochemical assessment. Results revealed that the highest phenolic compounds were in $S$. quettense when compared with other investigated taxa. In conclusion, molecular marker profiling together with phytochemical variation of all three species exhibited genetic diversity and chemical variation. The findings of the current investigation can further be used as a baseline study for the implementation of conservation strategies. In addition, phytochemical assessment can be utilized for modern drug discovery.
\end{abstract}

Keywords: Genetic variability, Hazarganji, phytochemicals, Seriphidium quettense, S. oliverianum, S. maritimum, Ziarat

\section{INTRODUCTION}

Seriphidium is the sub-genus of Artemisia belongs to the family Asteraceae. The habit of the genus is mostly herbs and shrubs. They are found in temperate climatic conditions frequently in dry or semi-dry habitats around the world. Seiphidium is the largest group within the genus Artemisia, and is considered as ecologically and economically important (Malik et al. 2017). Many species of this genus are known for their medicinal and other ethnobotanical uses. The known compounds from the genus are sesquiterpene lactones and terpenoids, making their taste bitter, producing strong aroma, and discouraging herbivores. Few species of this genus are also used as flavoring agents, food and some are used to repel insects (Shafiq et al. 2013; Ali et al. 2017). Phytochemical survey revealed that the genus Seriphidium produces essential oils and releases strong aroma, indicating volatile organic compounds (VOCs) (Shao et al. 2013; 2018). In recent world, these compounds are used as insecticides (Rizvi et al. 2020), bioherbicide (Shao et al. 2018), antioxidant and anticancer (Shafiq et al. 2013; Mokhtar et al. 2017; Liang et al. 2020), and many taxa are anthelmintic (Xie et al. 2019; Hussain et al. 2020). These compounds are natural and have no side effects. Pollination in this genus is through the wind-dispersed.

Seriphidium quettense (Podlech) is locally known as Zher or Terkha sperah. Synonym of Artemisia quettensis is a perennial, woody, aromatic shrublet endemic to Balochistan Province of Pakistan. The plant is well known for its medicinal and ornamental uses (Saeed et al. 2020).

Seriphidium oliverianum (J. Gay ex Besser) Bremer \& Humphries ex Y.R. Ling, Bull. is a synonym of Artemisia oliveriana. A densely arachnoid-tomentose to glabrescent or \pm glabrous, suffrutescent shrublet. The plant perennial and is abundantly found in Balochistan, Pakistan. Earlier various antioxidants were isolated from this plant and different biological activities investigated. Many important compounds like alkaloids, saponins, tannins, terpenoids, etc. are isolated from this species. The plant is also known for its use as anti-urease and anti-bacterial activities (Ali et al. 2017; Shafiq et al. 2017).

Seriphidium maritimum (L.) Poljakov is a synonym of Artemisia maritimum also found in Blochistan, Pakistan. It is also perennial and known as Sea wormwood. This species is not much used as a medicine. But some other ethnobotanical uses are well known about this species (Kumar et al. 2011).

In recent years molecular marker techniques are used to assess the genetic diversity of plants. The technique is also used for correct plant identification and the conservation of medicinally important taxa (Ahmed et al. 2020). The PCR-based methods are preferable because of their easiness and utilizing less quantities of sample DNA. The polymerase Chain Reaction (PCR) can widely be modified to perform a wide range of genetic manipulations. 
Studies on a number of RAPD and ISSRs markers provide a simple, potent, rapid, reproducible and low-cost means to assess genetic variability. RAPD and ISSR markers are the best, even if no prior information of the selected taxon is available. Further, such amplification does not require genome sequence information and leads to multilocus and highly polymorphic patterns (Sara et al. 2013).

This article deals with the genetic diversity in three Seriphidium species from different terrains of Balochistan, Pakistan. The species selected for molecular and phytochemical investigation are medicinally important, and the results may contribute to the conservation of threatened and endemic populations of the examined species.

\section{MATERIALS AND METHODS}

\section{Field surveys}

Field surveys were carried out over a two-year period (2018-2019) in different terrains of Balochistan, Pakistan, to investigate various Seriphidium species. Two mountainous ranges were selected for plant collection Ziarat (2,200-3,400 m asl.) and Hazarganji-Chiltan National Park mountain range from 1600-3300 masl (Figure 1). Field methods were followed as described by (Saeed et al. 2020).

\section{Sample collection}

Plant specimens were collected (in the replicates of three), identified and described morphologically. The voucher specimens were deposited in Botany Department, University of Balochistan, Quetta herbarium for future reference (Table 1 ).

\section{Morphology}

A total of 21 morphological characters were observed for morphological analysis listed in Table 3. Different magnifiers were used for observations of various parts.

\section{Phytochemical variation}

For phytochemical investigation, three samples were collected from each site. Total phenolic and flavonoid contents were estimated by using Double Beam Spectrophotometer (Hitachi u-2800).

\section{Flavonoids}

The method of Ordonez et al. (2006) was used for analysis of flavonoid contents. The amount of flavonoid measured at $420 \mathrm{~nm}$ absorbance. Total flavonoids contents were assessed by the quercetin $\left(\mathrm{mg} \mathrm{g}^{-1}\right)$ equation $\mathrm{Y}=0.0255 \times \mathrm{R} 2=0.9812$.

\section{Total phenolic contents}

The method by Slinkard and Singleton (1977) used to analyze total phenolic content was calculated at $765 \mathrm{~nm}$ absorbance. Total phenolic contents were expressed as $\mathrm{mg}$ $\mathrm{g}^{-1}$ tannic acid equivalent by the equation $\mathrm{Y}=0.1216 \times \mathrm{R} 2=0.9365$.

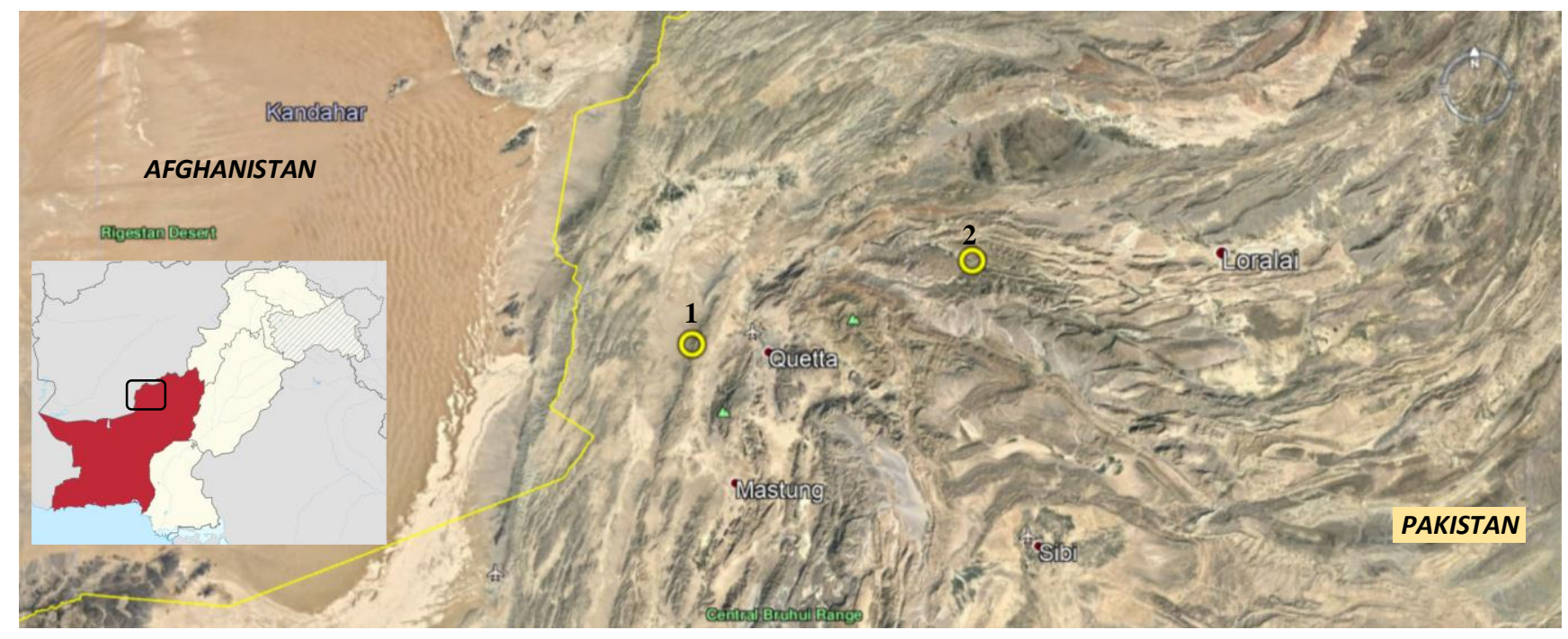

Figure 1. Map of Balochistan, Pakistan illustrating two study sites of plant sampling. 1. Hazarganji-Chiltan National Park, 2. Ziarat

Table 1. Name of plant species, voucher no. coordinates of study sites

\begin{tabular}{llllccc}
\hline \multicolumn{1}{c}{ Plant name } & Vern. name & Voucher no. & Locality & $\begin{array}{c}\text { Elevation } \\
\text { (m asl.) }\end{array}$ & Coordinates & Flowering period \\
\hline S. quettense & Zher / Tarkha & QUETTA000025 & Hazarganji & 2800 & $30.1312^{\circ} \mathrm{N} ; 66.4348^{\circ} \mathrm{E}$ & May-November \\
S. oliverianum & Tirkha & QUETTA000358 & Ziarat & 2500 & $30.3810^{\circ} \mathrm{N} ; 67.7270^{\circ} \mathrm{E}$ & August-September \\
S. maritimum & Tirkha sperah & QUETTA000121 & Ziarat & 2800 & $30.3810^{\circ} \mathrm{N} ; 67.7270^{\circ} \mathrm{E}$ & August-September \\
\hline
\end{tabular}




\section{Genetic diversity}

The DNA extraction was carried out by using the method of Doyle (1991) with few modifications The PCR reaction was carried out by using method of Saeed et al. (2017). A total of Twenty six primers (RAPD 17 and ISSR 09) were used (Table 2).

\section{PCR reaction}

The PCR reaction for amplification was carried out in total $20 \mu \mathrm{l}$ volume. The PCR master mix was prepared to contain $3 \mathrm{mM} \mathrm{MgCl} 2,1 \mathrm{X}$ PCR buffer, $0.2 \mathrm{mM}$ dNTPs mix, 20 pmol primers, $0.01 \%$ gelatin, $1 \mathrm{U} / \mathrm{rxn}$ Dream Taq DNA polymerase and $25 \mathrm{ng}$ DNA of template DNA. PCR amplification was performed using Applied Biosystems 96 well (USA), thermal cycler. For RAPD primers, PCR was programmed as mentioned below in table with initial denaturation at $94{ }^{\circ} \mathrm{C}$ for $3 \mathrm{~min}$ and then 36 cycles with denaturation at $94{ }^{\circ} \mathrm{C}$ for $1 \mathrm{~min}$, annealing temperature at $36{ }^{\circ} \mathrm{C}$ for $1 \mathrm{~min}$, extension step at $72{ }^{\circ} \mathrm{C}$ for 2 minutes and final extension for 5 minutes at $72{ }^{\circ} \mathrm{C}$. For ISSR primers, PCR was programmed as; initial denaturation at $94{ }^{\circ} \mathrm{C}$ for 3 min and then 40 cycles with denaturation at $94{ }^{\circ} \mathrm{C}$ for 1 min, annealing temperature $56^{\circ} \mathrm{C}$ for $1 \mathrm{~min}$, extension step at $72{ }^{\circ} \mathrm{C}$ for 2 minutes followed by an additional final extension for 5 minutes at $72{ }^{\circ} \mathrm{C}$. The amplified products were checked by electrophoresis in $1.8 \%$ agarose gels containing ethidium bromide $\left(0.5 \mu \mathrm{g} \mathrm{ml} \mathrm{m}^{-1}\right)$ in $1 \mathrm{X} \mathrm{TAE}$ buffer. The product was visualized by Gel documentation system under UV light and the size of markers was estimated by comparing it to the standard ladder (100 bp BIORON $0.2 \mathrm{mg} \mathrm{ml}^{-1}$ ) in the gel.

Table 2. Names and sequences of RAPD and ISSR used in analysis of genetic diversity

\begin{tabular}{lll}
\hline Name of marker & Sequence & $\begin{array}{c}\text { Size of } \\
\text { nucleotide }\end{array}$ \\
\hline RAPD & AGTCAGCCAC & 10 \\
OPA-3 & GAAACGGGTG & 10 \\
OPA-7 & GGGTAACGCC & 10 \\
OPA-9 & TTCCGAACCC & 10 \\
OPA-15 & GACCGCTTGT & 10 \\
OPA-17 & AGGTGACCGT & 10 \\
OPA-18 & GTTTCGCTCC & 10 \\
OPB-1 & GGACTGGAGT & 10 \\
OPB-4 & TGCTCTGCCC & 10 \\
OPB-6 & GTCCACACGG & 10 \\
OPB-8 & AGGGAACGAG & 10 \\
OPB-17 & GAACGGACTC & 10 \\
OPC-06 & GTCCCGACGA & 10 \\
OPC-07 & AAAGCTGCGG & 10 \\
OPC-11 & AAGCCTCGTC & 10 \\
OPC-13 & GACGGATCAG & 10 \\
OPC-15 & CACACTCCAG & 10 \\
OPC-16 & & \\
ISSR & (CAC)7T & 22 \\
ISSR-1 & (GA)9C & 19 \\
ISSR-2 & (CAC)7GT & 23 \\
ISSR-5 & (GA)8C & 17 \\
ISSR-15 & (CT)8G & 17 \\
ISSR-18 & (CA)8G & 17 \\
ISSR-21 & (GT)8C & 17 \\
ISSR-23 & (AC)8C & 17 \\
ISSR-29 & (AC)8G & \\
ISSR-30 & & \\
\hline
\end{tabular}

\section{Statistical analysis of data}

For analysis of genetic diversity molecular markers, data were scored as 1 (present) and 0 (absent). RAPD and ISSR data were clustered and dendrograms based on similarity matrices were calculated by using Sequential Agglomerative Hierarchical and Non-overlapping (SAHN) algorithm by "Unweighted Pair Group Method with Arithmetic Mean" (UPGMA) through Numerical by using NTSYS 2.10 (Rohlf 1998). Plant secondary metabolites (PSMs) were analyzed statistically by using XLSTAT version (2007). In the graphs, values presented are mean \pm SE. M. Morphological comparison was carried out by different qualitative and quantitative characters (Table 3). Three individuals per species were observed in the biometric analysis.

\section{RESULTS AND DISCUSSION}

The present study is the first comprehensive report on the morphological, chemical, and molecular diversity of three species of Seriphidium the one of the largest subgenus Artemisia groups. The data was collected from two high mountainous regions of Balochistan, Pakistan, i.e., Ziarat and Hazarganji-Chiltan National Park.

\section{Morphological diversity}

Life cycle and plant nature

Genus Seriphidium is a perennial shrub. S. quettense is perennial, woody and aromatic erect shrub. S. oliverianum is also woody and much-branched as compared to other two species. S. maritimum is perennial temperate shrub and aromatic similar to wormwood.

\section{Plant height and diameter}

Height of S. quettense is 38 to $40 \mathrm{~cm}$ and its diameter is $101 \mathrm{~cm}$. S. oliverianum is 40 to $60 \mathrm{~cm}$ tall with large diameter $125 \mathrm{~cm}$. The $S$. maritimum height range of 50 to $65 \mathrm{~cm}$ and diameter shorter than other two species $90 \mathrm{~cm}$.

\section{Plant surface and stem nature}

Plant surface presented in Figure 2. S. quettense is densely whitish hairy and color is pale green. Surface of $S$. oliverianum is densely arachnoid-tomentose to glabrescent and color is brownish yellow. The S. maritimum stem surface is also densely hairy and greenish in color.

\section{Leaf length and width}

Leaf length and width vary in all three species. Average leaf length and width of $S$. quettense is $2.7 \times 1.4 \mathrm{~cm}$ respectively. The length and width of $S$. oliverianum is 3.9 x $2 \mathrm{~cm}$ and $S$. maritimum is $2.2 \times 1.2 \mathrm{~cm}$, respectively.

\section{Leaf structure}

Leaf structure varies as $S$. quettense leaves punctateglandular covered with hair, greyish-green with petiole. Leaves of S. oliverianum are also long-petiole and oblong in shape. Leaves of S. maritimum are white and pinnatesect with numerous segments. 


\section{Flower}

Capitula of $S$. quettense is numerous and sessile, shape is ovate-oblong and arranged obliquely erect. S. oliverianum has sessile capitulum, oblong to narrowly ovate shape, arranged towards apices. S. maritimum inflorescence is generally in the form of a paniculate-raceme arrangement, flat and naked or covered by hair attached with small stalks Shape of flower is ovoid and aromatic.

\section{Flower size}

Seriphidium quettense flowers are 3.5-4.5 x $2 \mathrm{~mm}$ long, Flowers of $S$. oliverianum are $3-4 \times 1.5 \mathrm{~mm}$ long and the $S$. maritimum have short flowers of $2.5 \times 1 \mathrm{~mm}$ length.

\section{Flowering period}

Seriphidium quettense flower period is between May to November, which is a comparatively long period compared with other two species. Flowering period of S. oliverianum is very short between August and September. The flowering period of $S$. maritimum is between October to November.

\section{Genetic diversity}

The present work is based on two different molecular markers RAPD and ISSR. These primers are used for the first time on three species of this significant genus Seriphidium from Balochistan. The sizes of amplified bands were 250 to 1000 bp from RAPD, and 200 to 1700 bp from ISSR. Combined molecular marker system of RAPD and ISSR were used to generate a dendrogram and cluster analysis. The present approach revealed better results and low chance of error as described earlier by (Saeed et al. 2020; Saeed et al. 2017). Out of total of 35 used makers, 26 were amplified, 17 RAPD and 09 ISSR exhibited polymorphism revealed by reproducible bands amongst various Seriphidium species. Table 4 explains the characteristics of banding patterns obtained by primers. The amplified primers showed 231 loci and 111 were polymorphic (48\% polymorphism). The average bands scored per primers were 4.27 .

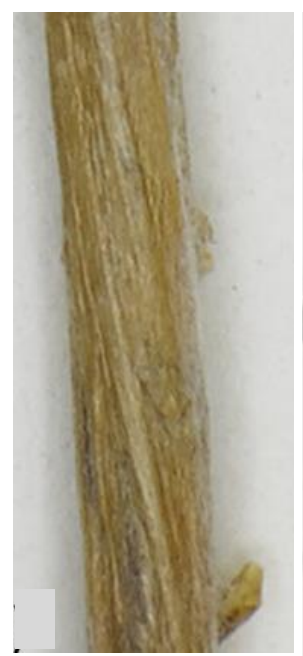

A

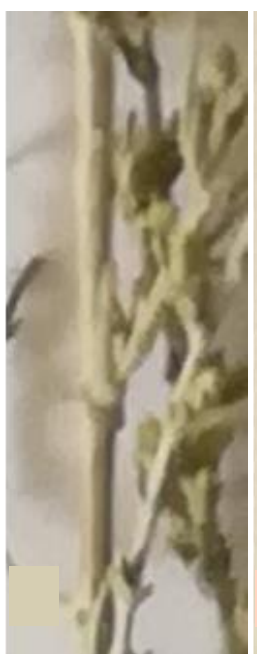

B B

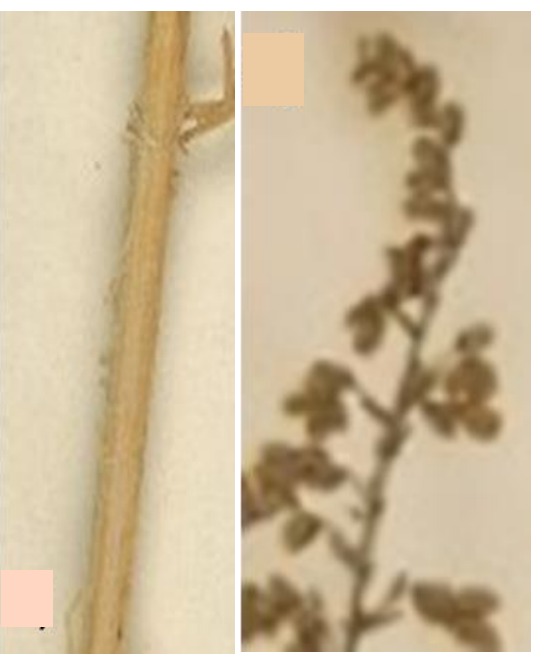

$\mathbf{A}$

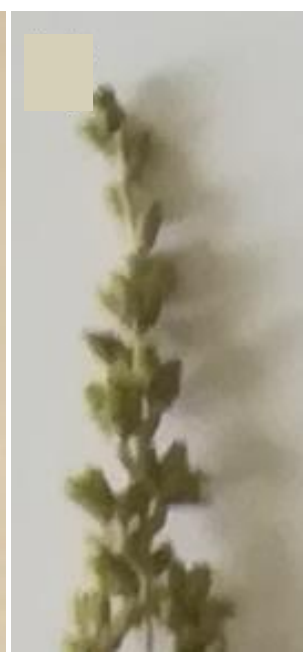

B

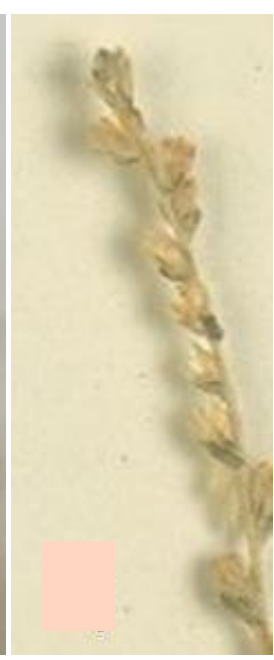

C
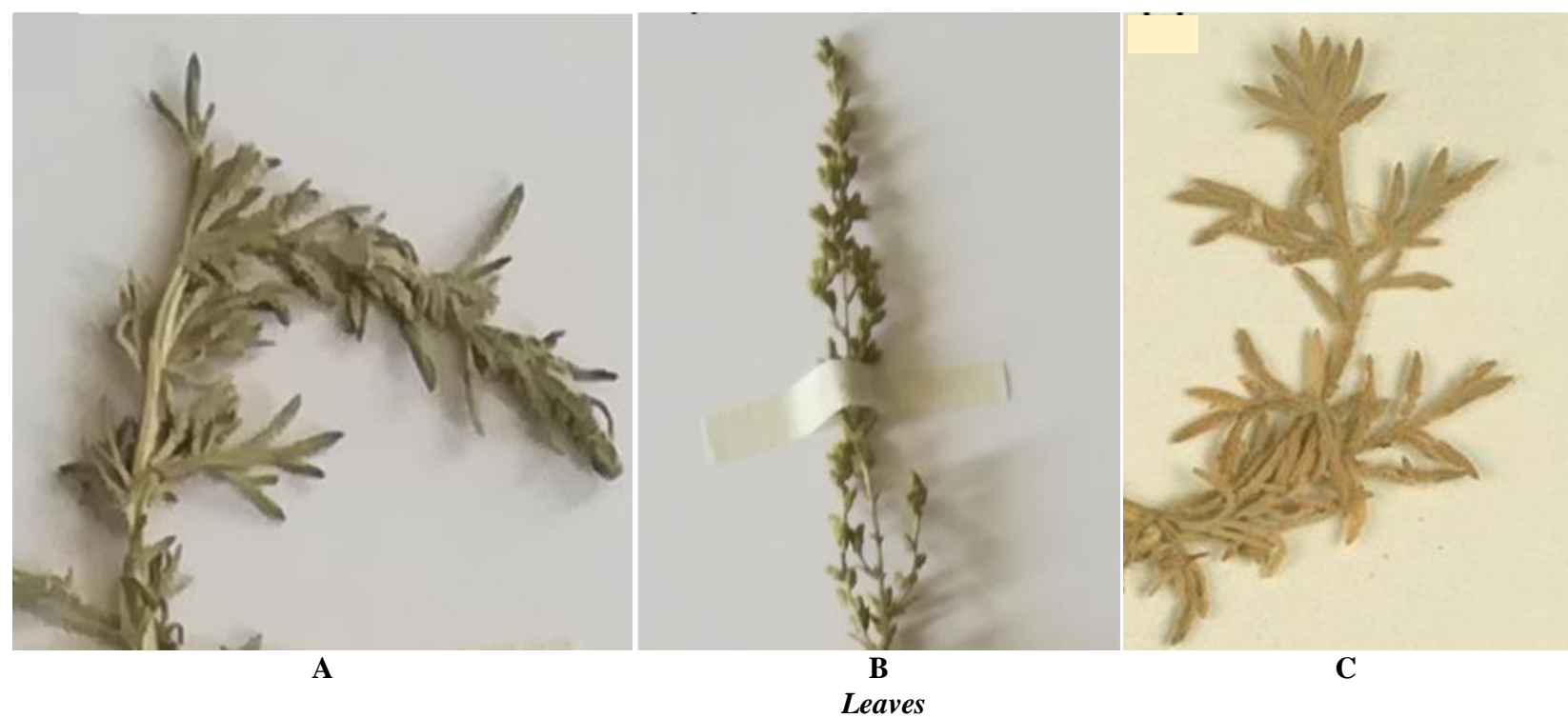

Leaves

Figure 2. Morphological variation of three species. A. Seriphidium maritimum, B. S. quettense, C. S. oliverianum 
Table 3. Morphological characteristics analysis of three species of Seriphidium

\begin{tabular}{llll}
\hline Characters & S. quettense & S. oliverianum & S. maritimum \\
\hline Qualitative & & & 60 \\
Plant length $(\mathrm{cm})$ & 38 & 56 & 96 \\
Plant width $(\mathrm{cm})$ & 101 & 125 & 2.4 \\
Leaf length $(\mathrm{cm})$ & 2.7 & 3.9 & 1.2 \\
Leaf Width $(\mathrm{cm})$ & 1.4 & 2 & 2.5 \\
Flower length $(\mathrm{mm})$ & 4 & 3.5 & 1 \\
Flower width $(\mathrm{mm})$ & 2 & 1.5 & Whitish green \\
Quantitative & & & Medium \\
Plant color & Greenish & Greenish-yellow & Greenish \\
Aromatic odor & High & Low & Wooly \\
Stem color & Pale green & Brownish-yellow & Entire \\
Stem texture & Wooly & Wooly & Present \\
Margin of leaf & Entire & Entire & Oblong \\
Leaf stipules & Present & Present & Acute \\
Leaf shape & Lobed & Oblong & Medium wooly \\
Leaf apex & Acute & Acute & Whitish \\
Leaf surface & Wooly & Medium wooly & Pinnate-sect \\
Leaf color & Greyish green & Greenish-yellow & Oblong \\
Type of leaf lobes & Pinnate-sect & Pinnate-sect & Flat \\
Shape of lobes & Oblong & Oblong & Raceme arrangement \\
Shape of head & Ovate-oblong & Oblong to narrowly ovate & October to November \\
Arrangement & Arranged obliquely erect & Arranged towards apices & \\
Flowering period & May to November & August and September & \\
\hline
\end{tabular}

Based on the amplified bands, data were subjected to cluster analyses shown in Figure 3. Two clusters A and B were obtained. Cluster A represented the population of $S$. quettense collected from Hazarganji-Chiltan National Park. $S$. quettense is the endemic species of the region. While Cluster B comprised of two species collected from Ziarat, i.e., S. oliverianum and S. maritimum.

\section{Chemical diversity}

Three species of Seriphidium were assessed for phytoconstituents. The total phenolic content (TPC) expressed as tannin equivalent and flavonoids content as quercetin equivalent within and among populations (Figure 4). The TPC ranged from 51 to $53 \mathrm{mg} \mathrm{g}^{-1}$ within the population of $S Q, 40$ to $42 \mathrm{mg} \mathrm{g}^{-1}$ within population of $S O$ and 40 to $43 \mathrm{mg} \mathrm{g}^{-1}$ within population of $S M$ (Table 4). Mean concentration of TPC across the populations was $45.37 \pm 1.89 \mathrm{mg} \mathrm{g}^{-1}$ whereas flavonoids showed diverse patterns within and among population. It ranged from 137 to $138 \mathrm{mg} \mathrm{g}^{-1}$ within population of $S Q$, while in population of $S O$ it ranged from 131-135 and population SM from 122$127 \mathrm{mg} \mathrm{g}^{-1}$. Mean concentration of flavonoids across the populations was $132 \pm 3.15 \mathrm{mg} \mathrm{g}^{-1}$.

\section{Discussion}

In the recent era, the indigenous folk medicines and traditional uses of herbs acquired importance in primary health care system. Most of the population of world depends upon medicinal plants and the phytochemicals isolated from these plants are being used for drug discoveries. Since the wild plants used in the drug discoveries, phytochemical screening and proper identification is required. Incorrect identification of plants due to similar morphological characters may cause loss in the production of herbal drugs.
Table 4. The number and type of amplified bands generated by seventeen RAPD and nine ISSR primers examined Seriphidium populations.

\begin{tabular}{|c|c|c|c|c|}
\hline $\begin{array}{l}\text { Name of } \\
\text { marker }\end{array}$ & $\begin{array}{c}\text { Annealing } \\
\text { temp. } \\
\left({ }^{\circ} \mathrm{C}\right)\end{array}$ & $\begin{array}{c}\text { Total } \\
\text { amplified } \\
\text { bands } \\
\end{array}$ & $\begin{array}{l}\text { Polymorphic } \\
\text { bands }\end{array}$ & $\begin{array}{l}\text { Polymorphic } \\
\text { bands } \\
\text { percentage }\end{array}$ \\
\hline \multicolumn{5}{|l|}{$\overline{\text { RAPD }}$} \\
\hline OPA-3 & 34 & 5 & 3 & 60 \\
\hline OPA-7 & 34 & 8 & 3 & 38 \\
\hline OPA-9 & 36 & 11 & 4 & 36 \\
\hline OPA-15 & 36 & 7 & 4 & 57 \\
\hline OPA-17 & 36 & 5 & 2 & 40 \\
\hline OPA-18 & 36 & 12 & 4 & 33 \\
\hline OPB-1 & 34 & 6 & 3 & 50 \\
\hline OPB-4 & 34 & 15 & 8 & 53 \\
\hline OPB-6 & 36 & 6 & 4 & 67 \\
\hline OPB-8 & 36 & 7 & 3 & 43 \\
\hline OPB-17 & 38 & 10 & 8 & 80 \\
\hline OPC-06 & 36 & 8 & 4 & 50 \\
\hline OPC-07 & 34 & 8 & 2 & 25 \\
\hline OPC-11 & 36 & 13 & 4 & 31 \\
\hline OPC-13 & 36 & 7 & 3 & 43 \\
\hline OPC-15 & 34 & 5 & 1 & 20 \\
\hline OPC-16 & 34 & 10 & 4 & 40 \\
\hline \multicolumn{5}{|l|}{ ISSR } \\
\hline ISSR-1 & 54 & 5 & 4 & 80 \\
\hline ISSR-2 & 52 & 8 & 6 & 75 \\
\hline ISSR-5 & 54 & 11 & 6 & 55 \\
\hline ISSR-15 & 50 & 7 & 3 & 43 \\
\hline ISSR-18 & 56 & 15 & 3 & 20 \\
\hline ISSR-21 & 52 & 10 & 6 & 60 \\
\hline ISSR-23 & 50 & 8 & 4 & 50 \\
\hline ISSR-29 & 56 & 16 & 10 & 63 \\
\hline ISSR-30 & 50 & 8 & 5 & 63 \\
\hline Total & & 231 & 111 & 48 \\
\hline
\end{tabular}


Table 5. Phytochemical composition representing mean \pm SD values

\begin{tabular}{lcc}
\hline Plant code & $\begin{array}{c}\text { Total phenolic } \\
\left(\mathbf{m g ~ g}^{-\mathbf{~}}\right)\end{array}$ & $\begin{array}{c}\text { Flavonoids } \\
\left(\mathbf{m g ~ g}^{-1}\right)\end{array}$ \\
\hline SQ1 & $42.15 \pm 0.78$ & $117.35 \pm 0.54$ \\
SQ2 & $41.32 \pm 1.25$ & $112.65 \pm 0.71$ \\
SQ3 & $40.18 \pm 1.44$ & $115.55 \pm 0.91$ \\
SO1 & $43.74 \pm 1.31$ & $102.25 \pm 1.24$ \\
SO2 & $42.58 \pm 0.86$ & $106.84 \pm 1.95$ \\
SO3 & $45.54 \pm 0.21$ & $101.51 \pm 3.12$ \\
SM1 & $51.64 \pm 1.19$ & $135.11 \pm 1.72$ \\
SM2 & $45.86 \pm 0.82$ & $130.82 \pm 1.94$ \\
SM3 & $46.29 \pm 2.14$ & $127.51 \pm 1.27$ \\
Mean average & $45.37 \pm 1.89$ & $132 \pm 3.15$ \\
\hline
\end{tabular}

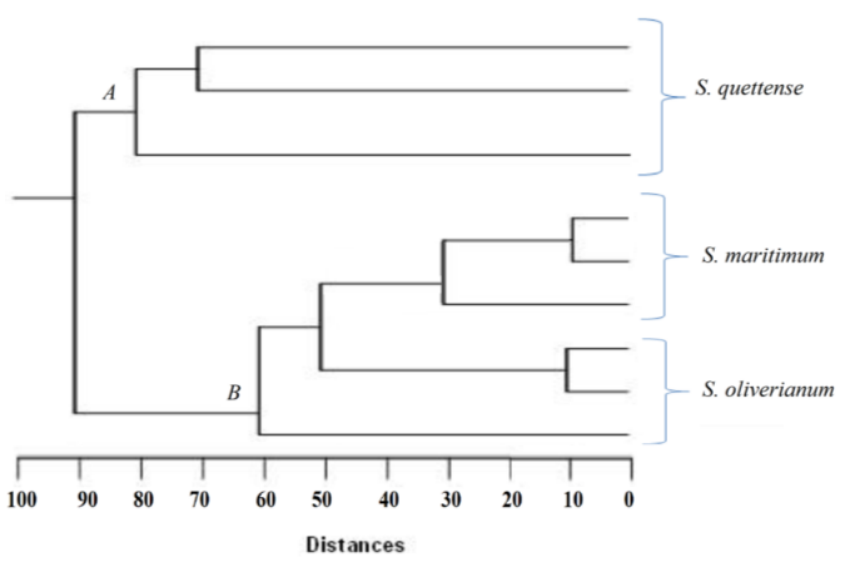

Figure 3. Cluster analyses based on molecular markers

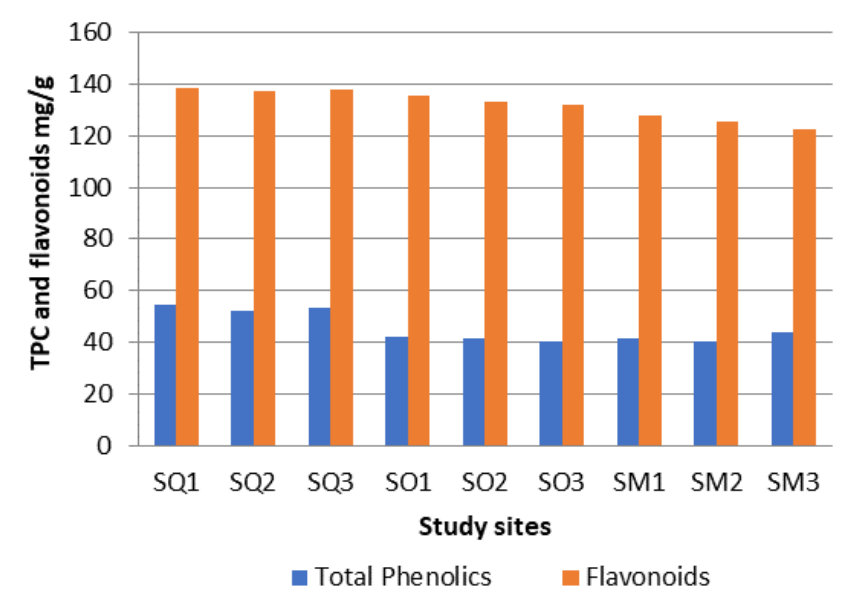

Figure 4. Patterns of phytochemical variations among different populations of Seriphidium

Molecular and morphological characterization resolves the misidentification of the taxa. Therefore, field surveys of Seriphidium plants have been undertaken in conserved region of Hazarganji-Chiltan National Park and Ziarat, Balochistan Pakistan. S. quettense, S. oliverianum, and $S$. maritimum were morphologically identified using taxonomic keys. The analysis of morphological criteria clearly reflects the differences among the populations of three Seriphidium species. Earlier $S$. quettense from various ecological zones of Balochistan was investigated (Saeed et al. 2020). Five species of Seriphidium from Balochistan Pakistan were characterized based on morphology (Peer et al. 2020). S. maritimum were characterized for its proper identification our finding is in agreement with its morphological characters (Kumar et al. 2011).

Genetic diversity plays an important role in the proper identification as well as planning of conservation of medicinally important taxa. The molecular marker system can be utilized to conservation medicinally important taxa (Saeed et al. 2016). Many researchers elucidated that change in the morphological characters may be due to harsh climate or weather. Plant adaptation property tends to alter their characteristics in response to any biotic factors. In the light of above-mentioned facts of morphological variation. The populations of $S$. quettense showed more variation within and among populations in comparison with other studied taxa that may be because the later is found in the same vicinity. This report contains genetic differences of three species of Seriphidium for the purpose of proper identification based on DNA fingerprinting by using RAPD and ISSR markers. A UPGMA tree exhibited the genetic distance amongst three populations of Seriphidium represented in Figure 2.

Results revealed a relatively high level of genetic distance of 0.80 of $S$. quettense when compared with the populations of $S$. oliverianum and $S$. maritimum that diverged at 0.61 and are closely related. Previously, Saeed et al. (2020) presented the highest degree of genetic similarity (0.53) that occurred between $S$. quettense from two different ecological zones of Balochistan. Phylogenetic studies provided the logical basis for classification of species. In current project, morphological characterization carried out along with the phytochemical and molecular characterization of various populations.

The selected plants are found to be used for medicinal purposes, total phenols and phenolic components were present. The similar level of total flavonoids found in all three species in our study is consistent with the results obtained by a photometric method exhibiting no significant differences. Total phenolics compounds varied from 40.18$54.41 \mathrm{mg} \mathrm{g}^{-1}$. Although the average Phenolic contents and flavonoid content observed for our study species was similar to those reported (Saeed et al. 2020). Earlier different antioxidant and anticancer compounds were reported from genus Seriphidium (Deng et al. 2013; Mohamed et al. 2010). our results suggested that other phytochemical investigations included GC-MS or HPLC may carry out for the studied taxa for isolation of medicinally important compounds from these three species.

The purpose of phytochemical investigation is to provide information about the best and suitable species of Seriphidium for further analysis. Further sequence analysis is strongly recommended for the authenticity of the species.

In conclusion, the present work on three species of Seriphidium in Balochistan, Pakistan reported here is an initial attempt that needs to be expanded towards a broad survey to validate the distribution of other species of 
Seriphidium. The ecological variations may have played a role in the genetic diversity of Seriphidium species in study area. Results of the study may be utilized for future sustainable conservation plans.

\section{REFERENCES}

Ahmed A, Hameed A, Saeed S. 2020. Ecological distribution, morphological and molecular characterization of Zygophyllaceae from diverse ecological zones of Balochistan, Pakistan. Appl Ecol Environ Res 18: 2445-2462. DOI: 10.15666/aeer/1802_24452462

Ali L, Tousif MI, Riaz N, Nazir M, Hussain H, Shafiq N, Jabbar A, Tareen RB, Saleem M. 2017. Nitrophenyl dihydropyridinederivatives from Seriphidium oliverianum. Phytochem Lett 21: 226229. DOI: 10.1016/j.phytol.2017.07.007

Deng YR, Song AX, Wang HQ. 2013. Chemical components of Seriphidium santolium Poljak. J Chin Chem Soc 51 (3): 629-636. DOI: $10.1002 /$ jecs.200400094

Doyle J. 1991. DNA Protocols for Plants. In: Hewitt GM, Johnston AWB, Young JPW. (eds) Molecular Techniques in Taxonomy. NATO ASI Series (Series H: Cell Biology). Springer, Berlin, Heidelberg. DOI: 10.1007/978-3-642-83962-7_18

Hussain A, Hayat MQ, Bokhari SAI. 2020. New distribution report on the alien species Artemisia verlotiorumlamotte (Asteraceae-Anthemideae) from Gilgit-Baltistan region of Pakistan. Pakistan J Weed Sci Res 26: 167. DOI: $10.28941 /$ pjwsr.v26i2.826

Kumar D, Bhat Z, Kumar V, Zargar M. 2011. A short review on Artemisia maritima Linn. Int J Res Phytochem Pharmacolog 1: 201-206.

Liang J-Y, Lu P-Y, Ning A-Q, Yang Y-Y, Shao Y-Z, Xu J. 2020 Chemical constituents from the aerial parts of Ajania fruticulosa. Biochem Syst Ecol 92: 104124. DOI: 10.1016/j.bse.2020.104124

Malik S, Vitales D, Qasim Hayat M, Korobkov AA, Garnatje T, Vallès J. 2017. Phylogeny and biogeography of Artemisia subgenus Seriphidium (Asteraceae: Anthemideae). Taxon 66: 934-952. DOI: $10.12705 / 664.8$

Mohamed AEH, El-Sayed MA, Hegazy ME, Helaly SE, Esmail AM, Mohamed NS. 2010. Chemical constituents and biological activities of Artemisia herba-alba. Rec Nat Prod 4 (1): 1-25. DOI: 10.13140/RG.2.1.2544.8806

Mokhtar MM, Shaban HM, Hegazy MEF, Ali SS. 2017. Evaluating the potential cancer chemopreventive efficacy of two different solvent extracts of Seriphidium herba-alba in vitro. Bulletin Faculty of Pharmacy, Cairo University 55: 195-201. DOI: 10.1016/j.bfopcu.2017.03.002
Ordonez A, Gomez J, Vattuone M. 2006. Antioxidant activities of Sechium edule (Jacq.) Swartz extracts. Food Chem 97: 452-458. DOI: 10.1016/j.foodchem.2005.05.024

Peer T, Gartner U, Badshah L. 2020. Morphological studies of the subgenus Seriphidium (Besser) Rouy of Artemisia L. in Balochistan (Pakistan). Pak J Bot 52: 711-722. DOI: 10.30848/PJB2020-2(44)

Rizvi SAH, Ling S, Zeng X. 2020. Seriphidium brevifolium essential oil: A novel alternative to synthetic insecticides against the dengue vector Aedes albopictus. Environ Sci Pollut Res 27: 31863-31871. DOI: 10.1007/s11356-020-09108-1

Rohlf F. 1998. NTSYS-pc version 2.0. Numerical taxonomy and multivariate analysis system Exeter software. Setauket, New York.

Saeed S, Ahmed A, Laghari S, Ali G, Begum S. 2020. Genetic and chemical variation of Seriphidium quettense endemic taxa of two mountainous regions of Quetta, Pakistan. Appl Ecol Environ Res 18: 2413-2423. DOI: 10.15666/aeer/1802_24132423.

Saeed S, Barozai MYK, Ahmed A, Tareen RB, Ali S. 2017. Impact of ecological diversity on genetic and phytochemical variation in Juniperus excelsa from high elevation zones of Quetta Valley, Pakistan. Pak J Bot 49: 201-206.

Saeed S, Barozai MYK, Ahmed A, Tareen RB, Begum S, Ali GM. 2016. Analysis of genetic diversity as a key to conserve Berberis baluchistanica Ahrendt: An endemic species to Balochistan. Proceedings of Pakistan Society for Horticultural Science. University of Agriculture, Faisalabad, Pakistan, 18-20 February 2016.

Shafiq N, Rafiq N, Saleem M, Rashid M. 2017. Phytochemical screening and biological evaluation of some potential constituents of Seriphidium oliverianum. Res J Life Sci Bioinformatic Pharm Chem Sci 32 (7): 37. DOI: 10.26479/2017.0302.03.

Shafiq N, Riaz N, Ahmed S, Ashraf M, Ejaz SA, Ahmed I, Saleem M, Touseef MI, Tareen RB, Jabbar A. 2013. Bioactive phenolics from Seriphidium stenocephalum. J Asian Nat Prod Res 15: 286-293. DOI: 10.1080/10286020.2013.763226.

Shao H, Hu Y, Han C, Wei C, Zhou S, Zhang C, Zhang C. 2018. Chemical composition and phytotoxic activity of Seriphidium terrae-albae (Krasch.) Poljakov (Compositae) essential oil. Chem Biodiver 15: e1800348. DOI: 10.1002/cbdv.201800348.

Shao H, Zhang Y, Nan P, Huang X, Zhang C. 2013. Chemical composition and phytotoxic activity of the volatile oil of invasive Xanthium italicum Moretti from Xinjiang, China. J Arid Land 5: 324330. DOI: 10.1007/s40333-013-0170-2.

Slinkard K, Singleton VL. 1977. Total phenol analysis: Automation and comparison with manual methods. Am J Enol Vitic 28: 49-55.

Xie F, Rizvi SAH, Zeng X. 2019. Fumigant toxicity and biochemical properties of $(\alpha+\beta)$ thujone and 1, 8-cineole derived from Seriphidium brevifolium volatile oil against the red imported fire ant Solenopsis invicta (Hymenoptera: Formicidae). Revista Brasileira de Farmacognosia 29: 720-727. DOI: 10.1016/j.bjp.2019.04.013. 